\title{
ONKO ETNOMUSIKOLOGIAN PUOLIINTUMISAIKA YKSI VUOSIKYMMEN?
}

Etnomusikologian vuosikirjaa on julkaistu vuodesta 1986 lähtien yhteensä 32 numeroa. Alkuvaiheessa kirja ilmestyi muutamaan otteeseen kaksoisnumerona, mutta pian tahdiksi vakiintui julkaisu per vuosi. Matkan varrelle on osunut pari näkyvää muutosta: Vuonna 1996 otettiin virallisesti käyttöön käsikirjoitusten vertaisarviointi. Vuonna 2010 puolestaan siirryttiin painotuotteesta verkkojulkaisuun. Kaiken kaikkiaan Etnomusikologian vuosikirjan sivuilla on julkaistu 305 artikkelia.

Viimeksi kuluneen vuosikymmenen aikana Etnomusikologian vuosikirjan artikkelimäärä on jäänyt vuositasolla suunnilleen puoleen siitä, mihin printtikaudella oli totuttu. Artikkeleiden lukumäärä on pysytellyt viiden ja seitsemän välillä, yksittäisenä poikkeuksensa yhdentoista artikkelin piikkivuosi 2016.

Liekö syynä muutokseen ollut siirtyminen verkkoformaattiin vai jokin muu? Toisaalta etnomusikologiankin ala on tuntunut käyneen yhä kansainvälisemmäksi juuri verkkoutumisen myötä, ja samalla Etnomusikologian vuosikirjan kansainväliset "kilpailijat" ovat tulleet saavutettavammiksi. Voidaan myös pohtia, miten viimeisen vuosikymmenen aikana tapahtuneet tiede- ja tutkimuskulttuurien muutokset ovat vaikuttaneet Etnomusikologian vuosikirjan kaltaisiin referee-julkaisuihin, mutta ehkä on viisainta paneutua näihin syihin jossakin muussa yhteydessä kuin lyhyessä johdantokirjoituksessamme. 
Sen sijaan kysymme: jatkuuko Etnomusikologian vuosikirjan puoliintuminen? Käsillä olevassa vuosikirjassa artikkeleita ilmestyy kolme. Se on vähemmän kuin koskaan aiemmin.

Artikkelien julkaisumäärä on tietenkin vain osatotuus. Se, miltä prosessin lopputulos näyttää, on eri asia kuin se, mitä julkaisun toimittajille tarjotaan. Vertaisarvioitujen tiedejulkaisujen maailmassa ei ole tavatonta, että osa toimitukselle lähetetyistä ehdotuksista kohtaa hylkäyspäätöksen jo prosessin alkuvaiheessa. Toisinaan eteneminen pysähtyy asiantuntijoiden ei niin mairitteleviin suosituksiin. Tuttu juonne tiedeartikkelien karsiutumistarinoissa on sekin, että kirjoittaja ilmoittaa itse luopuvansa käsikirjoituksensa kehittelystä.

Meillä ei ole tarkempaa tietoa siitä, missä määrin tämän vuoden karsiutumiset ovat linjassa Etnomusikologian vuosikirjan aiempien käytänteiden kanssa. Se on hyvä niin, tiedothan ovat luottamuksellisia. Sanotaan kuitenkin tämän vuoden osalta näin: näppituntumalta hylkäyksiä ja luopumisia tuli melko paljon. Voidaankin kysyä, tulisiko toimittajien katsoa peiliin. Tai onko syytä huolestua etnomusikologian tilasta?

Hylkäämiset ja muuten kesken jäävät artikkeliprosessit ovat ikäviä niin kirjoittajien kuin toimittajien kannalta, mutta ne ovat osa akateemista työtä. Syyt prosessin keskeytymiseen ovat moninaiset: Hyvä käsikirjoitus voi joutua hylätyksi heti alkuunsa, jos aihe menee liiaksi ohi julkaisun kriteereistä. Toisaalta kirjoittajan työtilanne, -aikataulu ja tavoitteet voivat muuttua, eikä käsikirjoituksen edistämiselle olekaan riittävästi aikaa tai voimavaroja - tänä koronavuonna muutokset tulivat kaikkien eteen yllättäen.

Toimitustyön tavoitteena on viimeistelty ja lukijaystävällinen koherentti kokonaisuus sekä artikkeli- että vuosikirjatasolla. Toimittajat ovat eräänlaisena välittäjänä kirjoittajien ja vuosikirjan välillä. He tukevat kirjoittajaa ja antavat rakentavaa palautetta. Toimittajien täytyy siis olla samalla aikaa rohkaisevia ja vaativia toimituskommenttien kanssa ja välittäessään vertaisarvioinnin lausuntoja kirjoittajille.

Toimittajien korjausehdotukset ja kommentit voivat joskus vaikuttaa nipottamiselta, ja ne herättävät kirjoittajissa varmasti suuttumuksenkin tunteita. Artikkeliprosessissa on mukana koko tunnekirjo onnistumisen ilosta pettymykseen ja epäonnistumiseen. Tunneskaalan ääripäät kuuluvat tutkijuuteen samoin kuin rohkeus ja sinnikkyys, jota tunteiden kohtaaminen ja työhön liittyvän epävar- 
muuden sietäminen vaativat. Ilman näitä ei synny uutta. Onnistumiset motivoivat ja antavat intoa tutkimukseen, pettymykset ja epäonnistumiset edistävät työtä toisella tapaa. Kriittiset vertaisarviolausunnot ja toimituskommentit pistävät ajattelemaan toiselta kantilta ja arvioimaan omaa työtä - ei vain kirjoittajana, vaan myös toimittajana.

Kaikilla osapuolilla on kuitenkin yhteinen päämäärä: prosessissa käsikirjoituksesta hiotaan onnistunut, napakka artikkeli.

Etnomusikologian tilasta ei edellä lueteltujen julkaisutilastojen perusteella tule vielä vetää liian suuria johtopäätöksiä, vaikka tilannetta on kyllä syytä pohtia. Se ainakin on ollut selvää, että mennyt vuosi on ollut poikkeuksellinen monessa mielessä: keväällä koronapandemian alkuvaiheessa, kun yliopistoihin, kirjastoihin ja arkistoihin ei ollut asiaa ja siirryttiin etätyöhön, moni totesi, ehkä pilke silmäkulmassa, että ensi vuonna oma julkaisumääräni nousee räjähdysmäisesti - tutkijathan eivät enää joutuisi istumaan pitkissä palavereissa. On ehkä liian aikaista kumota tällaista väitettä, mutta sanottakoon, että monelle tutkijalle on vuoden 2020 aikana kertynyt laaja kokemus etätyöstä ja -opetuksesta ja niihin liittyvistä kokouksista.

Nämä kokemukset epäilemättä näkyvät lähitulevaisuuden vuosikirjoissa. Julkaisujen lisäksi myös monet muut musiikkiin liittyvät käytännöt kuten live-keikat, opiskelu ja harrastaminen ovat siirtyneet verkkoon tai "hybridisoituneet", joten tulevissa vuosikirjoissa nähdään varmasti tähänkin liittyvää tematiikkaa. Koronapandemian vaikutus musiikkikulttuuriin merkitsee sitä, että tutkijoille kyllä riittää tutkittavaa - eritoten moninaisin etnomusikologisin näkökulmin olosuhteiden niin salliessa.

Etnomusikologian vuosikirjan artikkelien määrä on siis tänä vuonna vähäisempi kuin aiempina vuosina. Kirjan toimittajina uskallamme väittää, että kirjan sisällöllinen anti on silti runsas: nyt julkaistavat kirjoitukset ovat sekä etnomusikologisesti edustavia että laadukkaita.

Kolttasaamelaista musiikkiperinnettä pitkään tutkinut Marko Jouste tuo artikkelissaan "Suonikylän kolttasaamelainen itkuperinne 190o-luvulla" etnomusikologian tutkimuskentälle uuden kohteen: kolttasaamelaiset itkuvirret. Jouste kuvailee itkuperinteen käytäntöjä etnografisesti sekä analysoi itkujen musiikkia ja tekstejä arkistoaineistoja hyödyntäen. Artikkeli luo yleisluontoisen mutta perusteellisen katsauksen aiheeseen, joka nousi esiin arkistoaineistojen pienistä viit- 
teistä ja palasista. Lisäksi artikkeli selventää kolttasaamelaisen ja sen naapurin, karjalaisen kulttuurin yhteyksiä.

Heikki Uimonen ja Meri Kytö tarjoavat artikkelissaan "Toimimatonta tekniikkaa ja alitajuista vaikuttamista" etnomusikologisen näkökulman taustamusiikin tutkimukseen. Kirjoittajat tarkastelevat aluksi taustamusiikin historiallista jatkumoa Suomessa nostamalla esiin Muzak-yrityksen toimintaan liittyvää julkista diskurssia eri vuosikymmeninä. Tämän jälkeen artikkeli keskittyy joensuulaisessa kauppakeskuksessa tehdyn kenttätyön analysointiin laajeten lopuksi kehittämään aihepiiriin liittyvää teoretisointia ja metodologiaa.

Johannes Brusilan artikkelissa "'Vi dör ut. Ack, så tragiskt. Ack, så roligt.' Självironiskt förhandlande av finlandssvensk tillhörighet i internetmusikvideor" lähtökohtana on, että digitaalinen teknologia on mahdollistanut hauskojen musiikkivideoiden julkaisemisen perinteisten mediainstituutioiden ulkopuolella. Brusila pohtii, miten huumoria ja musiikkia voi käyttää musiikkivideoissa vähemmistöidentiteetin vahvistamiseen, kyseenalaistamiseen ja uusimiseen. Hauskat internetvideot ovat esimerkki siitä, miten ruotsinkieliset artistit Suomessa käsittelevät ja kehittelevät suomenruotsalaista yhteenkuuluvuutta.

Etnomusikologian vuosikirjan kirjoittajat ovat tänä vuonna saattaneet tekstinsä julkaisukuntoon poikkeuksellisissa olosuhteissa. Kiitämme tekijöitä kuten myös käsikirjoitusten lausunnonantajia heidän tärkeistä panoksistaan. Samalla toivomme ja uskomme, että kirjoituksia virtaa toimitukseen myös jatkossa. Oli kyse sitten historiallisista aiheista tai nykyisen musiikkikulttuurin murroksesta, etnomusikologista perinnettä hyödyntävälle tutkimukselle on 2020-luvulla sekä tilaa että tilausta. 